\title{
Social Media Marketing: Consumer Behavior on The Cruelty Free Concern of Beauty Brand
}

\author{
Wayan Weda Asmara Dewi ${ }^{1}$, Fitria Avicenna ${ }^{2}$ \\ 1,2Jurusan Ilmu Komunikasi, Universitas Brawijaya \\ Jl. Veteran Malang, 65145, Indonesia \\ Email: wedaasmaradewi@ub.ac.id ${ }^{1 *}$; \\ *corresponding author
}

\begin{abstract}
This research aims at beauty products that care about the "be cruelty-free" issue which means the company is not testing its products on animals. This study uses descriptive qualitative methods with interview instruments. Interview respondents will be selected by purposive sampling with the proviso that respondents are 17-35 years old, Instagram users, and have used beauty products for approximately 1 year. The results show that Instagram is a social media that is accessed almost every day, both to find entertainment, just fill in the time, and look for information. There is a possibility that the "be cruelty-free" issue is known through Instagram. The issue of "be cruelty-free" can be creatively packaged into information that attracts attention, is easily accessible and becomes a discussion topic on Instagram. Furthermore, "be crueltyfree" gives a positive impression that shows the company's concern for animal welfare and its impact on environmental balance in the long run. However, this issue is not a factor that directly influences individual benefits, so it does not have a dominant influence on purchasing decisions. What's more, consumers might not make repeat purchases, if the price is expensive. The contribution of this research is in the form of policy recommendations to companies to pay more attention to animal welfare by not testing products on animals. Keywords: social media marketing; cruelty free; consumen behavior.
\end{abstract}

\begin{abstract}
Abstrak
Penelitian ini bertujuan pada produk kecantikan yang peduli dengan isu "be cruelty-free" yang berarti perusahaan tersebut tidak mengujikan produknya pada hewan. Penelitian ini menggunakan metode kualitatif deskriptif dengan instrumen wawancara. Responden wawancara dipilih secara purposive sampling dengan syarat bahwa responden berumur 17-35 tahun, pengguna Instagram, dan sudah menggunakan produk kecantikan selama kurang lebih 1 tahun. Hasil menunjukkan bahwa Instagram menjadi media sosial yang diakses hampir setiap hari, baik untuk mencari hiburan, sekedar mengisi waktu, maupun mencari informasi. Terdapat kemungkinan isu "be cruelty free" diketahui melalui Instagram. Isu "be cruelty free" dapat dikemas secara kreatif menjadi informasi yang menarik perhatian, mudah diakses, dan menjadi topik diskusi di Instagram. Selanjutnya, "be cruelty free" memberikan kesan positif yang menunjukkan kepedulian perusahaan pada kesejahteraan hewan dan dampaknya pada keseimbangan lingkungan dalam jangka panjang. Isu ini bukanlah faktor yang berpengaruh secara langsung terhadap manfaat individu, sehingga tidak memberikan pengaruh yang dominan pada keputusan pembelian. Terlebih lagi, konsumen mungkin tidak akan melakukan pembelian ulang, jika harganya mahal. Kontribusi penelitian ini berupa rekomendasi kebijakan kepada perusahaan agar lebih memperhatikan lagi kesejahteraan kepada hewan dengan tidak menguji coba produk kepada hewan. Kata kunci: pemasaran media sosial; cruelty free; perilaku konsumen.
\end{abstract}

\section{Pendahuluan}

Humane Society International (HSI) merupakan penggagas awal yang mengajak lembaga lain untuk melarang penjualan kosmetik di Eropa yang diujicobakan pada hewan sejak 11 Maret 2013 (Seidle, 2013). Seidle (2013) juga menjelaskan bahwa ajakan tersebut kemudian dikemas dalam kampanye publik "be cruelty free" yang didukung selebritis terkemuka, kerjasama dengan sebuah merek kosmetik, dan dengan melakukan negosiasi dengan pihak politik.
Kampanye ini kemudian berkembang ke Australia, Brazil, Kanada, India, Korea, Selandia Baru, Rusia, dan Amerika Serikat. Perluasan kampanye tersebut berupaya untuk memberikan edukasi pada konsumen mengenai uji coba kosmetik pada hewan dan menyediakan sarana untuk mendukung kampanye tersebut. Sebagai alternatif uji coba hewan, produk kosmetik dapat melakukan uji coba dengan bahan kimia, pestisida, dan pengembangan teknologi manusia. 


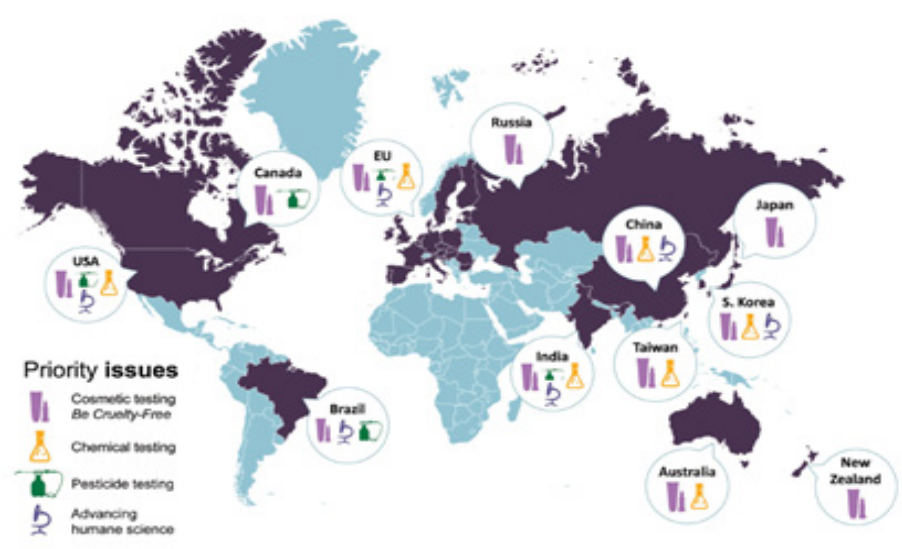

Gambar 1. Perluasan Kampanye "Be Cruelty Free" oleh HIS Sumber: dalam Seidle, (2013)

Seiring berkembangnya waktu, kampanye dapat lebih mudah disampaikan dengan adanya internet, khususnya sosial media. Menurut Kanat-Maymon et all. (2018), media sosial merupakan platform atau saluran online apapun yang memiliki potensi terbentuknya usergenerated content (UGC) karena ketersediaan kapasitas interaktif. Oleh karena itu, pengguna dapat berinteraksi dengan pengguna lain, baik perorangan maupun organisasi. Sebagaimana dikatakan oleh Leonardi, Huysman, dan Steinfield (2013), bahwa media sosial mempermudah organisasi untuk dapat berkomunikasi dengan pihak eksternal sebagai bagian dari ragam kampanye komunikasi. Selain itu, pengguna dapat ikut andil untuk mereproduksi pesan dengan kreativitas masingmasing untuk kemudian disampaikan pada pengguna lainnya. Hal tersebut memungkinkan sebuah kampanye untuk tersebar lebih cepat.

Dengan keunggulan media sosial yang telah disebutkan di atas, tidak heran jika pengguna aktif media sosial terus meningkat. Data dari Statista (2018) menunjukkan bahwa sekitar 2 milyar orang menggunakan media sosial pada tahun 2018. Salah satu yang menarik perhatian adalah Instagram, sebagai platform dengan peningkatan pengguna paling cepat. Per Juli 2018, instagram memiliki 1 milyar pengguna aktif (Statista 2018). Oleh karena itu, studi ini akan fokus pada penyebaran kampanye melalui Instagram. Instagram sebagai metode pemasaran produk kosmetik dengan kampanye "be cruelty free" juga telah menjangkau Indonesia. Dengan nama lain, seperti "no animal testing” maupun "anti-animal cruelty",kampanyeinimemilikisatu tujuanbahwa produk tersebut tidak di uji coba pada hewan. Beberapa produk kosmetik telah menunjukkan kepeduliannya dengan ikut melakukan kampanye tersebut dan melakukan edukasi pada pengguna Instagram mengenai pentingnya untuk peduli pada hal tersebut (gambar 2). Berkembangnya kampanye tersebut di Indonesia menjadi motivasi kajian penyebaran kampanye tentang produk kosmetik yang tidak di uji coba ke hewan melalui media sosial. Beberapa studi di Indonesia (Pangestu 2017; Sabami 2017) mengkaji kampanye "forever against animal testing". Studi tersebut khusus membahas tentang bagaimana edukasi tersebut sampai ke konsumen produk the Body Shop. Dari studi yang ada nampak kesenjangan kajian, seperti kemampuan media yang digunakan dalam menyampaikan kampanye tersebut.

Berdasar penjelasan di atas, penelitian ini bertujuan pada produk kecantikan yang peduli dengan isu "be cruelty-free" yang berarti perusahaan tersebut tidak mengujikan produknya pada hewan. Penelitian ini fokus pada tiga poin penting, yaitu: 1) kemampuan Instagram 

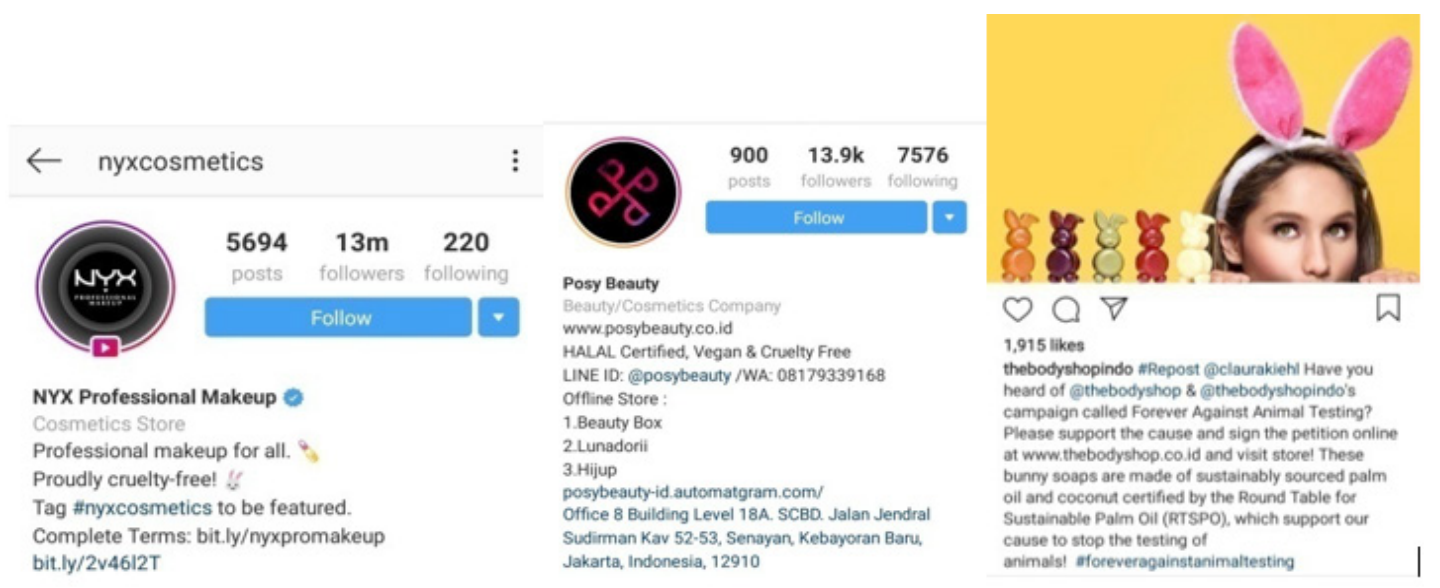

Gambar 2. Produk kosmetik yang ada di Indonesia dengan kampanye "be cruelty free" Sumber: Instagram akun@nyxcosmetic,@posybeauty, @thebodyshopindo, (2018)

sebagai metode pemasaran dari kampanye "be cruelty free" atau yang memiliki makna sejenis; 2) pemahaman pengguna Instagram tentang kampanye "be cruelty free"; dan 3) pengaruh kampanye "be cruelty free" pada pemilihan dan penggunaan produk kosmetik dan perawatan badan. Selanjutnya, hasil studi ini diharapkan dapat memperkaya kajian tentang media sosial sebagai metode pemasaran (social media marketing) dan perilaku konsumen terhadap kampanye dengan isu keseimbangan lingkungan.

\section{Social Media}

Media sosial Instagram Sebagai Metode Pemasaran Teknologi informasi dan komunikasi di Indonesia semakin berkembang. Hal tersebut didukung oleh Asosiasi Penyelenggara Jasa Internet Indonesia (APJII 2013) bahwa perkembangan teknologi informasi dan komunikasi di Indonesia dewasa ini sudah menyentuh seluruh kalangan, termasuk masyarakat umum, pemerintah, dan bisnis. APJII bekerjasama dengan Polling Indonesia (APJII 2016) melakukan survei perilaku penggunaan internet di Indonesia. Hasil riset secara signifikan menunjukan penggunaan media sosial menduduki peringkat tertinggi yaitu 97,4\% (129,2 juta) dari daftar jenis konten internet yang diakses.
Gupta dan Walter (dalam Saragih dan Sinay 2014) menambahkan, pesatnya pertumbuhan pengguna internet Indonesia menunjukkan pergeseran pola komunikasi bisnis dari media konvensional, seperti media cetak dan elektronik, yang meliputi surat kabar, majalah, radio, dan televisi untuk media baru yaitu media digital. Media sosial juga termasuk dalam kategori media baru (McQuail 2005). Media sosial adalah sebuah platform komunikasi dimana anggota kelompok bersosialisasi dan berbagi informasi. Seperti yang diungkapkan oleh Lin \& Liu (dalam Han dan Kim 2016) media sosial terdiri dari lingkungan online yang memungkinkan orang untuk berbagai informasi (seperti, teks, gambar, audio dan video) dengan satu sama lain. Pada awalnya media sosial digunakan untuk berinteraksi dengan individu yang satu dengan lainnya. Media sosial membuat seseorang berkomunikasi dengan ratusan bahkan ribuan yang lain. Seiring perkembangannya, internet banyak dimanfaatkan bukan sekedar sebagai alat komunikasi, mencari informasi dan hiburan, berdagang (e-commerce), hingga berjualan (shopping). Dalam hal ini komunikasi yang terjadi bersifat transaksional. Proses komunikasi cenderung bersifat dua arah dimana perusahaan 
dapat berkomunikasi langsung dengan konsumen melalui saluran media sosial dan konsumen dapat langsung memberikan feedback (Widyastuti, dalam Sulhan dan Adiputra 2012).

Menurut Weinberg (2009) pemasaran social media adalah proses yang memberdayakan individu dan perusahaan untuk mempromosikan situs web, produk, atau layanan mereka melalui saluran sosial online dan untuk berkomunikasi dengan dan memasuki komunitas yang jauh lebih besar yang mungkin tidak tersedia melalui saluran periklanan konvensional. Social media menghubungkan penyedia layanan, perusahaan dan perusahaan dengan khalayak luas influencer dan konsumen. Weber (2009) berpendapat bahwa pemasaran social media tidak hanya ditujukan untuk perusahaan multinasional besar. Perusahaan kecil dan menengah pun dapat memanfaatkan pemasaran social media dengan efektif dan mengambil keuntungan yang maksimal dari cara tersebut.) Social media bukan hanya metode pemasaran namun secara efektif telah menjadi cara baru dalam menjalankan bisnis (Smith dan Zook 2011).

Dari teori-teori diatas dapat disimpulkan bahwa pemasaran melalui social media dapat mempermudah kegiatan pemasaran dikarenakan dapat mencapai target audiens yang luas dan perusahaanpun dapat dengan mudah menentukan segmentasi konsumen yang dituju. Terdapat banyak social media yang dapat digunakan sebagai metode pemasaran, salah satunya ialah Instagram. Dalam website resminya www.instagram.com disebutkan bahwa Instagram adalah sebuah aplikasi dan layanan berbagi foto berbasis seluler, desktop dan berbasis internet yang memungkinkan pengguna berbagi gambar dan video baik secara publik, atau secara pribadi terhadap pengikut yang telah disetujui sebelumnya yang diciptakan oleh Kevin Systrom dan Mike Krieger (Instagram 2018).

\section{Social Media Marketing}

Berdasarkan penelitian terdahulu oleh Godey et al. (2016) Dior, Gucci, Hermès, and Louis Vuitton dengan judul "Social Media Marketing Efforts of Luxury Brands: Infuence on Brand Equity and Consumer Behavior" Social Media Marketing Efforts memiliki lima unsur utama; yaitu Entertainment, Interaction, Trendiness, Customization dan Word of Mouth. Unsurunsur tersebut memiliki keunggulan tersendiri dan mempunyai keuntungan bagi perusahaan apabila menggunakan lima unsur tersebut dalam perannya di social media perusahaan. Adapun unsur-unsur dalam social media marketing yaitu: 1) Entertainment atau hiburan adalah hasil yang didapat dari kesenangan dan permainan yang muncul dari pengalaman menggunakan social media; 2) Interaction atau interaksi pada dasarnya dapat mengatur komunikasi antara perusahaan dengan pelanggan; 3) Trendiness atau kekinian dari social media dapat memberikan terbaru dan topik yang dapat didiskusikan; 4) Customization atau kustomisasi personalisasi dalam social media perusahaan, sebuah brand dapat dikustomisasi, mengekspresikan simbol perusahaan dan membangun afinitas dan loyalitas brand; 5) Word of Mouth atau informasi dari mulut ke mulut dalam social media berguna dalam interaksi oleh konsumen kepada konsumen tentang sebuah produk.

Dari kelima unsur dari Social Media Marketing tersebut, dikatakan bahwa social media marketing adalah bagian dari promotional mix dalam paradigma komunikasi yang baru (Mangold dan Faulds 2009) the impact of consumer-to-consumer communications has been greatly magnified in the marketplace. This article argues that social media is a hybrid element of the promotion mix because in a traditional sense it enables companies to talk to their customers, while in a nontraditional sense it enables customers to talk directly to one another. The content, timing, and frequency of the social media-based conversations occurring 
between consumers are outside managers'direct control. This stands in contrast to the traditional integrated marketing communications paradigm whereby a high degree of control is present. Therefore, managers must learn to shape consumer discussions in a manner that is consistent with the organization's mission and performance goals. Methods by which this can be accomplished are delineated herein. They include providing consumers with networking platforms, and using blogs, social media tools, and promotional tools to engage customers (Mangold and Faulds 2009. Social media marketing memberikan pemasar kesempatan yang lebih besar untuk menjangkau konsumen di komunitas sosial mereka dan membangun lebih banyak hubungan pribadi dengan konsumen (Kelly, Kerr, dan Drennan 2010). Hubungan Media Sosial Instagram sebagai Alat Pemasaran dengan Perilaku Konsumen

Melihat kesuksesan komunikasi pemasaran dengan menggunakan media sosial instagram, membuat peneliti ingin mencari hubungan antara penggunaan instagram sebagai media komunikasi pemasaran oleh sebuah brand terhadap keputusan pembelian konsumen. Keunggulan dari instagram yang dipaparkan sebelumnya, tidak secara spesifik merujuk pada karakteristik brand tertentu yang berhasil dipasarkan lewat media sosial instagram. Peneliti melihat banyak terdapat case studies bisnis dari berbagai macam brand dari pakaian, makanan, alat kecantikan, website travel hingga wedding planner di seluruh dunia yang berhasil secara nyata dengan menggunakan instagram sebagai media komunikasi pemasaran mereka yang ada pada website resmi instagram. Salah satu contoh clothing brand Levis. Brand ini mengambil keuntungan dari instagram dengan menggunakan konten tertentu, seperti yang dikatakan Mungula selaku consumer marketing Mexico Levis bahwa perusahaan Levis adalah clothing brand, tetapi instagram memungkinkan mereka untuk menggambarkan gaya hidup.
Brand ini ingin menghasilkan relevansi antara target audiens Meksiko, membangun dirinya sebagai cara hidup dan menggambarkan garis perempuan baru untuk meningkatkan penjualan. Levis memposisikan diri di antara target audiens orang dewasa muda berusia 18-35 tahun yang tinggal di Meksiko dan tertarik dengan musik, seni, festival, celana jeans, belanja dan pakaian.

Levis melakukan kampanye di instagram yang disebut \#LiveInLevis. Kampanye tersebut terdiri dari iklan foto carousel, serta iklan video pendek. Dalam iklan tersebut di hadirkan koleksi terbaru Levis dengan tiga titik fokus, yaitu penggunaan, gaya dan personalisasi. Hal ini untuk memberi ide kepada target audiens untuk bagaimana menggunakan produkproduknya. Komunikasi pemasaran ini berjalan cepat, mudah untuk ditonton karena konten iklan ini persis seperti apa yang target audiens ingin melihat. Video pendek yang ditampilkan secara ekslusif oleh instagram, mencapai $68 \%$ biaya lebih rendah per-tampilan dibandingkan dengan platform media sosial lainnya. Ingatan tentang iklanjuga meningkat 6\% dibandingkan kelompok kontrol. Dan penjualan koleksi perempuan meningkat sebesar $30 \%$ di toko-toko ritel.

Kesuksesan lainnya dengan menggunakan instagram sebagai alat komunikasi pemasaran datang dari brand John Lewis. Angela Bertram selaku Social Community Manager, John Lewis mengaku instagram sangat cocok untuk industri fashion. John Lewis ingin meningkatkan kesadaran koleksi pakaian musim gugur dan musim dingin, retail asal Inggris ini melakukan komunikasi pemasaran produk pakaian nya yaitu bermitra dengan beberapa blogger asal Inggris dan influencer instagram untuk kampanye selama enam minggu di instagram, mereka diperbolehkan untuk mengeksplorasi ide-ide baru, termasuk "get the look" video. Dengan melakukan komunikasi pemasaran melalui instagram, John Lewis mampu mencapai audiens anak muda dan wanita untuk mendorong brand dan niat pembelian. Hasilnya, John Lewis mendapatkan 
peningkatan 14 poin niat pembeli konsumen wanita antara 25-34 tahun. Keterlibatan sosial juga meningkat, dengan followers instagram hampir dua kali lipat dari 14.000 menjadi 24.000. Dengan memanfaatkan kekuatan dari instagram, John Lewis mampu memberikan sendiri brand tampilan baru sebagai pemimpin fashion.

\section{Metode Penelitian}

Metode penelitian ini adalah kualitatifdengan tataran analisis deskriptif. Menurut Moleong (2004), penelitian kualitatif adalah penelitian yang bermaksud untuk memahami fenomena tentang apa yang dialami oleh subyek penelitian secara holistik, dan dengan cara deskripsi dalam bentuk kata-kata dan bahasa, pada suatu konteks khusus yang alamiah dan dengan memanfaatkan berbagai metode alamiah. Pendapat Patton (dalam Ruslan 2003) menekankan bahwa dalam penelitian ini, realitasnya bersifat ganda dan kompleks, satu sama lainnya saling berhubungan sehingga merupakan satu kesatuan yang bulat atau holistik. Selanjutnya, penggunaan tataran deskripsi bertujuan untuk membuat deskripsi secara sistematis, faktual, dan akurat tentang fakta-fakta dan objek tertentu (Kriyantono 2006). Tujuan penelitian kualitatif ini untuk mendapatkan pemahaman yang sifatnya umum terhadap kenyataan sosial dari perspektif partisipan (Ruslan 2003). Terkait dengan penelitian bagaimana persepsi konsumen terkait sosial media marketing pemasaran tentang cruelty-free, fokus pada merek produk kecantikan untuk mempromosikan kesadaran dan perilaku ramah lingkungan.

Guna mencapai tujuan tersebut, data yang dibutuhkan dikumpulkan dengan cara wawancara dan dokumentasi. Wawancara dilakukan dengan informan yang mempunyai kriteria, yaitu: 1) Berjenis kelamin perempuan dan Laki-laki; 2) Umur 17 sampai 35 tahun; 3) Mempunyai media sosial Instagram; 4) Menggunakan produk Kecantikan baik kosmetik maupun skincare.

Dengan demikian, maka objek penelitian ini adalah 1) kemampuan Instagram sebagai metode pemasaran dari kampanye "be cruelty free" atau yang memiliki makna sejenis; 2) pemahaman pengguna Instagram tentang kampanye "be cruelty free"; dan 3) pengaruh kampanye "be cruelty free" pada pemilihan dan penggunaan produk kosmetik dan perawatan badan. Guna mencapai tujuan tersebut, subyek penelitian ini adalah orang-orang yang mengikuti akun (followers) dari akun @nyxcosmetics, @ posybeauty, dan@thebodyshopindo. Secara khusus, informan dipilih secara purposive sampling memiliki kriteria, yaitu: 1) Berjenis kelamin perempuan dan Laki-laki; 2) Umur 17 sampai 35 tahun; 3) Mempunyai media sosial Instagram; 4) Menggunakan produk Kecantikan baik kosmetik maupun skincare.

Data yang dibutuhkan dikumpulkan dengan cara wawancara dan dokumentasi. Wawancara dilakukan pada informan, dan dokumentasi merupakan data dari ketiga akun yang diteliti dan penelitian maupun artikel berita terkait. Selanjutnya, data wawancara akan dikategorisasi sesuai objek penelitian, begitupun dengan data dokumentasi. Selanjutnya analisis dilakukan pada data yang telah diproses, kemudian deskripsi atas hasil analisis dipaparkan sesuai tujuan penelitian.

\section{Hasil Penelitian dan Pembahasan Instagram sebagai Social Media Marketing}

Belakangan ini media sosial sangat diminati oleh masyarakat Indonesia dilihat dari data statistic survey oleh We Are Social pada bulan Januari 2018, jumlah pengguna aktif media sosial di Indonesia sebanyak 130 juta pengguna. Hasil wawancara mengenai seberapa sering informan mengakses media social, menunjukkan bahwa semua responden mengakses media social Instagram hampir setiap hari, baik untuk mencari hiburan, sekedar mengisi waktu, maupun mencari informasi. Sesuai dengan salah satu manfaat dari social media menurut Puntoadi (2011) adalah bahwa Social media memberikan kesempatan untuk berinteraksi lebih dekat dengan 
konsumen dan social media menawarkan bentuk komunikasi yang lebih individual. Melalui social media para pemasar dapat mengetahui kebiasaan konsumen mereka dan melakukan interaksi secara personal serta membangun keterikatan yang lebih dalam. Terkait isu "be cruelty free", responden kebanyakan tidak begitu mengingat apakah mereka awalnya mengetahui hal tersebut dari Instagram atau tidak. Akan tetapi, responden juga tidak memungkiri jika mungkin saja mereka mendapatkan informasi terkait "be cruelty free" melalui Instagram.

Hal yang menarik adalah ketika mereka ditanyakan mengenai apakah mereka paham atau tidak mengenai "be cruelty free", sebagian informan merasa tidak familiar dengan kata "be cruelty free". Namun, ketika dijelaskan bahwa isu "be cruelty free" adalah tentang produk kecantikan yang tidak melakukan uji coba pada hewan, responden mengerti akan hal tersebut. Responden juga mengetahui bahwa produk kecantikan akan menggunakan label terkait "be cruelty free" jika memang produk mereka tidak melakukan uji coba pada hewan.

Dari hasil wawancara informan mendapatkan informasi terkait "be cruelty free" melalui interaksi dengan pengguna Instagram lainnya. Interaksi dapat terjadi di kolom komentar maupun secara personal. Pernyataan tersebut didukung berdasarkan penelitian terdahulu oleh Godey et al. (2016)Dior, Gucci, Hermès, and Louis Vuitton dengan judul "Social Media Marketing Efforts of Luxury Brands: Infuence on Brand Equity and Consumer Behavior" Social Media Marketing Efforts memiliki lima unsur utama, salah satunya adalah Word of Mouth atau informasi dari mulut ke mulut dalam social media berguna dalam interaksi oleh konsumen kepada konsumen tentang sebuah produk.

Trendiness atau kekinian dari social media dapat memberikan topik terbaru yang dapat didiskusikan terdapat pada pesan yang tersebar melalui tagar (\#), misalnya \#foreveragainstanimaltesting yang diusung oleh
The Body Shop. Keragaman bentuk informasi yang tersedia di Instagram karena komunikator atau perusahaan produk kecantikan dapat secara kreatif membingkai pesan terkait "be cruelty free" sesuai segmen pasar yang ingin dijangkau sehingga Customization atau kustomisasi personalisasi dalam social media perusahaan dapat mengekspresikan simbol perusahaan dan membangun afinitas dan loyalitas brand. Berdasarkan penelitian terdahulu oleh Godey et al. (2016) Dior, Gucci, Hermès, and Louis Vuitton dengan judul "Social Media Marketing Efforts of Luxury Brands: Infuence on Brand Equity and Consumer Behavior" Social Media Marketing Efforts memiliki lima unsur utama; yaitu Entertainment, Interaction, Trendiness, Customization dan Word of Mouth. Unsurunsur tersebut memiliki keunggulan tersendiri dan mempunyai keuntungan bagi perusahaan apabila menggunakan lima unsur tersebut dalam perannya di social media perusahaan.

\section{Perilaku Konsumen terhadap Isu "Be Cruelty Free" pada Produk Kecantikan}

PETA (People for the Ethical Treatment of Animals) menyebutkan beberapa merek kosmetik International cruelty-free termasuk NYX dan Body Shop. Selain brand kosmetik internasional, brand lokal Indonesia juga mulai memedulikan istilah cruelty-free dalam proses pembuatan produknya, hal ini dibuktikan dengan banyaknya bermunculan berbagai macam konten yang dibuat oleh beauty enthusiast yang membahas tentang produk cruelty-free terutama dalam kosmetik dan dunia kecantikan. Produk cruelty-free sudah menjadi perhatian bagi kalangan pecinta hewan, mereka cenderung untuk memilih produk yang berlabel crueltyfree dalam pemilihan produk kosmetiknya.

Hasil wawancara menunjukkan bahwa dengan mengetahui adanya kampanye "be cruelty free" memberikan kesan positif pada konsumen. Konsumen menganggap bahwa perusahaan tidak semata-mata hanya berfikir tentang hasil akhir 
maupun bahan produksi dalam pembuatan produk kecantikan, namun juga memperhitungkan dampak dari uji coba pada hewan terhadap keseimbangan lingkungan. Akan tetapi, kampanye tersebut tidak banyak berpengaruh pada pemilihan sebuah produk kosmetik. Hal tersebut karena muncul banyak batasan bagi konsumen ketika memilih dan membeli produk kosmetik. Hasil studi (van Riemsdijk dkk. 2017) menunjukkan bahwa produk yang ramah hewan cenderung lebih mahal sehingga pilihan produk yang tersedia akan lebih terbatas.

Dalam keputusan pembelian produk kecantikan, seorang konsumen pasti mempertimbangkan beberapa nilai (value) yang dimiliki sebuah produk yang akan memberikan manfaat bagi konsumen. Beberapa studi (Schmitt 1999; Smith dan Colgate n.d.; Sheth, Newman, dan Gross 1991) menunjukkan bahwa nilai yang dipertimbangkan seperti nilai uang (pengorbanan ekonomi dalam bentuk harga yang harus dibayar), nilai fungsional (misalnya, bedak mampu menutupi bekas jerawat), nilai sensoris (misalnya, aroma), nilai sosial (misalnya, status) dan nilai etis, yang mencakup produk ramah hewan. Sehingga, ketika konsumen memasukkan isu "be crulety free" dalam evaluasi produk kecantikan, maka sebuah produk tidak hanya dinilai dari harga, packaging, maupun fungsi produk yang ditawarkan. Aspek kepedulian pada hewan juga menjadi faktor yang diperhitungkan.

Jika memperhitungkan isu "be cruelty free", maka akan berkaitan dengan dua jenis nilai. Pertama, isu "be cruelty free" adalah masalah sosial yang penting (Bennett 1995). Konsumen yang memperhitungkan isu tersebut umumnya percaya bahwa perlakuan yang manusiawi terhadap hewan adalah hal yang benar dan etis untuk dilakukan (Ingenbleek dkk. 2012), sehingga dengan memilih produk yang ramah hewan memiliki dampak positif pada total nilai dalam produk yang dirasakan khususnya nilai etis. Kedua, produk kecantikan yang ramah hewan pada umumnya dijual dengan biaya tambahan (Den Ouden dkk. 1997) sehingga harga produk akan bertambah. Disisi lain, hal tersebut menjadi tantangan penting bagi pemasaran produk-produk ramah hewan.

Hal ini menjadi dilema sosial yang mencerminkan situasi ketika pilihan yang diambil memaksimalkan kesejahteraan individu jangka pendek berdampak negatif bagi kesejahteraan sosial jangka panjang (Messick 1983). Kesejahteraan individu mengacu pada manfaat individu, yang dinikmati oleh konsumen individu atau lingkungan sosial langsungnya, seperti keluarga, sementara kesejahteraan sosial mengacu pada manfaat sosial, yang dibagi oleh kelompok sosial yang lebih besar. Oleh karena itu, kesejahteraan hewan dapat dikonseptualisasikan sebagai manfaat sosial, juga disebut sebagai manfaat public (Messick 1983; Brewer dan Kramer 1986). Nilai uang atau harga produk kecantikan, di sisi lain, menguntungkan konsumen itu sendiri.

Dalam situasi seperti itu, sebagian besar konsumen cenderung memilih produk yang memaksimalkan kesejahteraan individu mereka, daripada produk yang memaksimalkan kesejahteraan sosial. Ini karena evolusi lebih banyak disukai orang-orang yang telah menempatkan kepentingan diri mereka di atas (jangka panjang) kepentingan masyarakat (Griskevicius, Cantú, dan Vugt 2012). Dengan kata lain, manusia telah berevolusi untuk memiliki kecenderungan yang kuat untuk memprioritaskan kepentingan pribadi atas kepentingan masyarakat dan untuk menghargai manfaat saat ini lebih dari yang di masa depan (Griskevicius, Cantú, dan Vugt 2012).

Selain harga dan pilihan produk yang terbatas, hasil wawancara menunjukkan bahwa keputusan pembelian produk kosmetik masih sangat banyak dipengaruhi oleh peran endorser. Pesan yang disampaikan oleh endorser akan lebih mudah diterima oleh konsumen. Akan tetapi, isu terkait produk yang ramah hewan kurang banyak disampaikan. Endorser lebih 
banyak menyampaikan tentang bahan baku (ingredients) sebuah produk, bagaimana produk tersebut setelah digunakan, dan bagaimana kesan positif serta negatif produk tersebut. Influencer media sosial dapat berpengaruh terhadap kepekaan calon konsumen tentang informasi terhadap produk yang hendak digunakannya. Seperti penelitian yang dilakukan oleh Novi Tri Hariyanti dan Alexander Wirapraja (2018) yang meneliti tentang pengaruh influencer marketing sebagai strategi pemasaran digital di era modern. Hasil penelitian menunjukkan bahwa pemasaran melalui media sosial sangat berpotensi untuk pemasaran pada era moderen saat ini melalui perangkat pribadi, selain itu influencer marketing juga dapat meningkatkan brand image dan secera efektif dapat meningkatkan brand awareness konsumen terhadap merek tertentu.

Berdasarkan literatur pemasaran tentang faktor penentu pilihan produk konsumen telah menyoroti beberapa faktor yang saling terkait yang mendorong pilihan produk konsumen, seperti kualitas produk, nilai total yang dirasakan produk, dan kepuasan pelanggan (Hellier dkk. 2003; Tsiotsou 2006; Cronin dkk. 2000). Hal tersebut juga menguatkan penjelasan sebelumnya bahwa konsumen lebih fokus pada manfaat yang didapat individu.

Hasil wawancara juga menunjukkan bahwa, jika konsumen sudah memiliki sebuah produk kecantikan dan setelah itu konsumen baru mengetahui bahwa produk ternyata juga mengusung "be cruelty free" dengan label terkait, maka nilai produk tersebut akan bertambah positif. Hal tersebut akan menguatkan si konsumen bahwa mereka telah memilih produk dengan benar dan tidak ada beban sosial. Sehingga konsumen melakukan pembelian ulang produk tersebut. Hal tersebut dibuktikan dengan penelitian oleh Riemsdijk dkk (2017) yang memaparkan bahwa ketika konsumen harus memilih diantara animal friendly dan produk biasa, konsumen akan dihadapkan dengan dilema sosial yang mengharuskan mereka untuk menukar nilai keuangan dengan kepentingan kesejahteraan hewan, sehingga konsumen akan lebih memilih produk yang baik pula terhadap hewan. Kecenderungan masyarakat yang sudah mulai paham dengan pentingnya untuk memilih kosmetik cruelty-free juga meningkatkan minat beli mereka terhadap produk tersebut dengan alasan untuk meningkatkan kesejahteraan dan hak untuk hidup bagi hewan.

\section{Simpulan}

Instagram menjadi media sosial yang diakses hampir setiap hari, baik untuk mencari hiburan, sekedar mengisi waktu, maupun mencari informasi. Walaupun tidak ingat pasti, hasil penelitian ini menunjukkan bahwa terdapat kemungkinan isu "be cruelty free" diketahui melalui Instagram. Isu "be cruelty free" dapat dikemas secara kreatif menjadi informasi yang menarik perhatian, mudah diakses, dan menjadi topik diskusi di Instagram. Hal tersebut menjadikan instagram sebagai media yang dipilih menjadi metode pemasaran kampanye ini.

Terkait pemahaman tentang isu yang dikampanyekan, isu "be cruelty free" secara umum sudah diketahui oleh konsumen produk kecantikan yang menjadi responden, apabila dijelaskanmaknanya.Merekamendapatkankesan positif karena "be cruelty free" menunjukkan kepedulian perusahaan produk kecantikan pada kesejahteraan hewan dan dampaknya pada keseimbangan lingkungan dalam jangka panjang.

Akan tetapi, isu "be cruelty free" belum menjadi faktor yang sama pentingnya dengan faktor-faktor yang berpengaruh secara langsung terhadap manfaat yang diperoleh individu yang menggunakan produk tersebut, sehingga keberadaan label "be cruelty free/no animal testing" tidak memberikan pengaruh yang dominan pada keputusan pembelian. Terlebih lagi, konsumen mungkin tidak melakukan pembelian ulang pada produk kecantikan yang telah digunakan, dengan pengalaman positif yang telah dialami, jika harganya mahal. Dapat 
disimpulkan bahwa label "be cruelty free or no animal testing" pada sebuah produk kosmetik memang membawa kesan positif, namun jika harganya mahal, maka akan berpengaruh pada pemilihan dan penggunaan produk tersebut.

Selain hasil penelitian di atas, sebagai tambahan, kebaruan penelitian ini tampak dalam jenis produk kosmetik yang dipilih bukan termasuk produk luxury atau high end, seperti yang dinyatakan dalam penelitian terdahulu yang kami gunakan. Salah satu produk yang digunakan dalam penelitian ini ada juga yang merupakan produk lokal, yaitu posy beauty. Kedua poin tersebut menunjukkan bahwa isu sosial mulai menjadi daya tarik yang digunakan produk kosmetik secara umum, tidak hanya produk berskala internasional, juga produk lokal. Kontribusi penelitian ini berupa rekomendasi kebijakan kepada perusahaan agar lebih memperhatikan lagi kesejahteraan kepada hewan dengan tidak menguji coba produk kepada hewan.

\section{Daftar Pustaka}

APJII. (2013). "Survei Penggunaan Internet Sektor Bisnis 2013." Asosiasi Penyelenggara Jasa Internet Indonesia (APJII). 2013. https://apjii.or.id/content/read/39/28/SurveiPenggunaan-Internet-Sektor-Bisnis-2013. APJII. (2016). "Saatnya Jadi Pokok Perhatian Pemerintah Dan Industri." https://apjii.or.id/downfile/file/ BULETINAPJIIEDISI05November2016. pdf.

Bennett, Richard. (1995). "The Value Of Farm Animal Welfare." Journal of Agricultural Economics, 46(1). Wiley/ Blackwell (10.1111): 46-60. https://doi. org/10.1111/j.1477-9552.1995.tb00751.x.

Brewer, MB, and RM Kramer. (1986). "Choice Behavior in Social Dilemmas: Effects of Social Identity, Group Size, and Decision Framing." Journal of Personality and Social 50: 543-549. http:// doi.apa.org/journals/psp/50/3/543.html.
Cronin, J Joseph, Michael K Brady, G Tomas, and $M$ Hult. (2000). "Assessing the Effects of Quality, Value, and Customer Satisfaction on Consumer Behavioral Intentions in Service Environments." Journal of Retailing 76 (2): 193-218. Godey, Bruno, Aikaterini Manthiou, Daniele Pederzoli, Joonas Rokka, Gaetano Aiello, Raffaele Donvito, and Rahul Singh. (2016). "Social Media Marketing Efforts of Luxury Brands: Influence on Brand Equity and Consumer Behavior." Journal of Business Research 69 (12). Elsevier: 5833-41. https:// doi.org/10.1016/J.JBUSRES.2016.04.181.

Griskevicius, Vladas, Stephanie M Cantú, and Mark van Vugt. (2012). "The Evolutionary Bases for Sustainable Behavior: Implications for Marketing, Policy, and Social Entrepreneurship." Journal of Public Policy \& Marketing 31 (1): 11528. https://doi.org/10.1509/jppm.11.040. Han, Min Chung, and Youjeong Kim. (2016). "Can Social Networking Sites Be E-Commerce Platforms?" Pan-Pacific Journal of Business Research 7 (1): 24-39. https:// doi.org/10.1002/meet.2011.14504801096. Hariyanti, N. T., \& Wirapraja, A. (2018, Juni). Pengaruh Influencer Marketing Sebagai Strategi Pemasaran Digital Era Moderen (Sebuah Studi Literatur). Jurnal Eksekutif, 15. Hellier, Phillip K., Gus M. Geursen, Rodney A. Carr, and John A. Rickard. (2003). "Customer Repurchase Intention." European Journal of Marketing, 37 (11/12): 1762-1800. https:// doi.org/10.1108/03090560310495456. https://wearesocial.com/blog/2018/01/ g 1 ob a $1-d i g$ it a $1-$ report -2018 Ingenbleek, Paul T.M., Victor M. Immink, Hans A.M. Spoolder, Martien H. Bokma, and Linda J. Keeling. (2012). "EU Animal Welfare Policy: Developing a Comprehensive Policy Framework." Food Policy 37 (6), 690-99. https://doi. org/10.1016/J.FOODPOL.2012.07.001. 
Instagram. (2018). "About Us • Instagram." Instagram. 2018. https:// www.instagram.com/about/us/. Kanat-Maymon, Y., Almog, L., Cohen, R., \& Amichai-Hamburger, Y. (2018). Contingent self-worth and Facebook addiction. Computers in Human Behavior, 88,227-235. doi: 10.1016/j.chb.2018.07.011.

Kelly, Louise, Gayle Kerr, and Judy Drennan. (2010). "Avoidance of Advertising in Social Networking Sites." Journal of Interactive Advertising 10(2). Routledge: 16-27. https:// doi.org/10.1080/15252019.2010.10722167.

Kriyantono, R. (2006). Teknik Praktis: Riset Komunikasi. Jakarta: PT Kencana Prenada Media Group. Leonardi, Paul M., Marleen Huysman, and Charles Steinfield. (2013). "Enterprise Social Media: Definition, History, and Prospects for the Study of Social Technologies in Organizations." Journal of Computer-Mediated Communication 19 (1). Oxford University Press: 1-19. https://doi.org/10.1111/jcc4.12029.

Mangold, W. Glynn, and David J. Faulds. (2009). "Social Media: The New Hybrid Element of the Promotion Mix." Business Horizons 52 (4). Elsevier: 357-65. https:// doi.org/10.1016/J.BUSHOR.2009.03.002.

McQuail, Denis. (2005). Mass Communication Theory. London: Sage Publication Ltd. Messick, DM. (1983). "Solving Social Dilemmas." Review of Personality and Social, 11-44. https:// ci.nii.ac.jp/naid/10030484937/.

Moleong, Lexy J. (2004). Metodologi Penelitian Kualitatif. Bandung: Remaja Rosdakarya.

Ouden, M. Den, J.T. Nijsing, A.A. Dijkhuizen, and R.B.M. Huirne. (1997). "Economic Optimization of Pork Production-Marketing Chains: I. Model Input on Animal Welfare and Costs." Livestock Production Science 48 (1). Elsevier: 23-37. https://doi. org/10.1016/S0301-6226(96)01411-X.
Pangestu, Priscilla Elizabeth. (2017). "Kajian Kampanye Edukasi;Forever Against Animal Testing; Humas The Body Shop Indonesia Melalui Media Sosial." LSPR Jakarta. Puntoadi, Danis. (2011). Menciptakan Penjualan melalui Social Media. Jakarta: PT.Elex Media Komputindo Riemsdijk, Lenka van, Paul Ingenbleek, Hans van Trijp, and Gerrita van der Veen. (2017). "Marketing Animal-Friendly Products: Addressing the Consumer Social Dilemma with Reinforcement Positioning Strategies." Animals 7 (12). Multidisciplinary Digital Publishing Institute: 98. https://doi.org/10.3390/ani7120098.

Ruslan, Rosady. (2003). Metode Penelitian PR Dan Komunikasi. Jakarta: PT. Raja Grafindo Persada. Sabami,Dheasya Rahmaunisa.(2017). “Tingkat Pengetahuan Konsumen The Body Shop Surabaya Mengenai Kampanye Forever Against Animal Testing." Universitas Katolik Widya Mandala Surabaya. Saragih, F. D., and D. T. Sinay. (2014). "Trustworthiness Perception and Decision to Conduct Transactions through E-Commerce Websites in Indonesia." International Journal of Administrative Science \& Organization 21 (3): 137-45. www.apjii.or.id. Schmitt,Bernd.(1999). "ExperientialMarketing." Journal of Marketing Management 15 (1-3). Taylor \& Francis Group : 53-67. https:// doi.org/10.1362/026725799784870496.

Seidle, Troy. (2013). "Humane Society International's Global Campaign to End Animal Testing." Alternative to Laboratory Animals 41: 453-59. Sheth, JN, BI Newman, and BL Gross. (1991). "Why We Buy What We Buy: A Theory of Consumption Values." Journal of Business Research 22 (2): 159-70.

Smith, J.Brock, and Mark Colgate.n.d. "Customer Value Creation: A Practical Framework." 
Journal of Marketing Theory and Practice. Taylor \& Francis, Ltd. Accessed August 6, 2018. https://doi.org/10.2307/40470272. Smith, P. R. (Paul Russell), and Ze. Zook. (2011). Marketing Communications: Integrating Offline and Online with Social Media. Kogan Page. statista. (2018). "Leading Global Social Networks 2018 | Statistic." https://www. statista.com/statistics/272014/global-socialnetworks-ranked-by-number-of-users/. Sulhan, M, and Wisnu Martha Adiputra. (2012). "The 3rd International Communication Research Conference,
Jakarta." In The 3rd International Communication Research Conference. Tsiotsou, Rodoula. (2006). "The Role of Perceived Product Quality and Overall Satisfaction on Purchase Intentions." International Journal of Consumer Studies 30 (2): 207-17. https:// doi.org/10.1111/j.1470-6431.2005.00477.x. Weber,Larry.(2009). Sticks\&Stones :HowDigital Reputations Are Created over Time and Lost in a Click. New Jersey: John Wiley \& Sons, Inc. Weinberg, Tamar. 2009. The New Community Rules: Marketing on the Social Web - Tamar Weinberg - Google Buku. CA: O'Reilly Media, Inc. 